\title{
Nanowhisker structures of copper oxide under conditions of exposure to temperature fields and corrosive media
}

\author{
N. N. Gryzunova ${ }^{\dagger}$, A. A. Vikarchuk, V. V. Bekin, V.S. Firsov, A. M. Gryzunov \\ †'gryzunova-natalja@yandex.ru
}

Togliatti State University, 14 Belorusskaya str., Togliatti, 445020, Russia

\begin{abstract}
Copper oxide nanowhiskers are of interest as potential sensors, photodetectors, catalysts, and photocatalysts. The paper presents the data of studies related to the problems of using copper (II) oxide nanowhiskers under the effects of temperature fields and corrosive environment. As such effects, reactions of catalytic oxidation of carbon monoxide and methyl alcohol (methanol) are considered. Arrays of nanowhiskers are obtained by annealing two types of copper coatings in an oxygencontaining atmosphere. One type of the coatings was grown by the method of electrodeposition with a mechanical activation of the cathode, and the other one - without it. In the former case, coatings consisting of large defect crystals were formed, and in the latter one, coatings composed of nanocrystalline copper were formed. It is shown that, in both cases, annealing of copper coatings resulted in the formation of layers consisting of copper oxides. Both coatings showed high activity under the catalytic oxidation of carbon monoxide and methyl alcohol, but the sample obtained without mechanical activation during electrodeposition entered into the reaction much earlier than the sample obtained with mechanical activation. This may be due to a higher concentration of whiskers on the surface of the first sample. However, during prolonged tests, the activity of the first sample decreased more rapidly than the one of the sample obtained with mechanical activation. In the authors' opinion, the decrease in the activity of the samples in oxidation reactions is due to the fracture of nanowhiskers which is caused by the change of the crystal lattice size due to their partial reduction. Applications of nanowhiskers are proposed.
\end{abstract}

Keywords: nanowhiskers, fracture, temperature fields, corrosive media.

УДК: $544-971.2,53.096$

\section{Нановискерные структуры оксида меди в условиях воздействия температурных полей и агрессивных сред}

\author{
Грызунова Н.Н. ${ }^{\dagger}$ Викарчук А. А., Бекин В. В., Фирсов В. С., Грызунов А. М. \\ Тольяттинский государственный университет, ул. Белорусская 14, Тольятти, 445020, Россия
}

Нановискеры оксида меди представляют интерес в качестве потенциальных сенсоров, фотодетекторов, катализаторов, фотокатализаторов. В работе приведены данные исследований, связанных с проблемами применения нановискеров оксида меди (II) в условиях воздействия на них температурных полей и агрессивных сред. В качестве такого воздействия рассматриваются реакции каталитического окисления окиси углерода II и метилового спирта (метанола). Массивы нановискеров получали отжигом медных покрытий двух видов в кислородосодержащей среде. Один вид покрытий выращивали методом электроосаждения с механической активацией катода, а другой - без нее. В первом случае формировались покрытия, состоящие из крупных дефектных кристаллов, а во втором случае - из нанокристаллической меди. Показано, что и в том и в другом случае отжиг медных покрытий приводит к формированию в них слоев, состоящих из оксидов меди. При каталитическом окислении окиси углерода и метилового спирта оба покрытия показали высокую активность, однако образец, полученный без механической активации во время электроосаждения, вступал в реакцию значительно раньше, чем образец, полученный с механической активацией, что может быть связано с более высокой концентрацией вискеров на поверхности первого образца. Однако при длительных испытаниях его активность снижалась быстрее, чем активность образца, полученного с механической активацией. По мнению авторов, снижение активности образцов в реакциях окисления происходит из-за разрушения нановискеров, причиной которого служит изменение размера кристаллической решетки в результате их частичного восстановления. Предложены области применения нановискеров.

Ключевые слова: нановискеры, разрушение, температурные поля, агрессивные среды. 


\section{Introduction}

Nanosized particles and whiskers of base metals and their oxides are of great interest lately. Nanoparticles find expanding applications as catalysts $[1-5]$ and photocatalysts [6-8], and whisker structures can be applied in microelectronics. In particular, there are publications [9-11] that describe potential fields of applications of whisker structures of copper oxide $(\mathrm{CuO})$ as anodes for lithium-ion batteries, gas sensors, photodetectors, field-emission displays. Furthermore, whiskers are tested for photocatalytic properties $[10,12,13]$. The most promising ways to create arrays of nanowhiskers of $\mathrm{CuO}$ are chemical and electrochemical methods of obtaining copper crystals and their further heat treatment in oxygencontaining medium [9-12]. During such processing, nanowhiskers of $\mathrm{CuO}$ with the density of $10^{8}-10^{9} \mathrm{~cm}^{-2}$ are formed on the surface of copper crystals, films or coatings $[11,12]$. It is shown in $[10,11]$ that nanowhiskers of $\mathrm{CuO}$ obtained by such methods have unique mechanical properties at room temperature, in particular, flexural strength close to the theoretical one $\left(6.6 \times 10^{10} \mathrm{~Pa}\right)$. There are, however, no data on the structural stability of these nanowhiskers in the temperature fields and corrosive media. The goal of the present work is to explore the features of the behavior of the nanowhisker arrays of copper (II) oxides $(\mathrm{CuO})$ in corrosive media and temperature fields. Reactions of catalytic oxydation of carbon (II) monoxide (CO) and methyl alcohol (methanol) oxydation were used as corrosive media.

\section{Experiment}

In the present work the arrays of copper oxide $(\mathrm{CuO})$ nanowhiskers were obtained by means of two processing operations.

By means of the first operation, coatings of two types, one of nanocrystalline copper (Fig. 1a) and the other one of microcrystalline copper (layers of crystals, which contain disclination type growth defects and are further referred to as defect crystals (Fig. 1b)) were obtained. The coatings of nanocrystalline copper (further referred to as sample I) were obtained by electrochemical deposition from solutions of electrolyte on a mesh from stainless steel $12 \mathrm{X} 18 \mathrm{H} 10 \mathrm{~T}$ with the cell size of $40 \times 40 \mu \mathrm{m}$ and the wire diameter of $30 \mu \mathrm{m}$. Aqueous solution of $25 \mathrm{wt} \%$ copper sulphate with addition of $5 \mathrm{wt} \%$ sulphuric acid was used as the electrolyte. The mesh was connected to the cathode of the potentiostat and immersed into the electrolyte. The deposition was carried out in the potentiostatic mode at $160 \mathrm{mV}$ overvoltage for 15-25 minutes using P-150J potentiostat by Elins. The surface morphology is shown in Fig. 1a.

The procedure of obtaining the layers of defect microcrystals (sample II) had the only difference from the first way that an activator in the form of microparticles of metal oxides were added to the agitated electrolyte in the beginning of electrocrystallization, due to which a mechanical activation of the cathode and copper crystals growing on it was performed [13-16]. The morphology of such a surface (further referred to as sample II) is shown in Fig. 1b. The mechanical activation occurred due to an effect of abrasive particles of a powder composed of aluminium and silicon oxides in the approximate ratio 1:1 moving in the electrolyte, which are inert to the cathode. The average size of the particles amounted to $10-25 \mu \mathrm{m}$. The activation of the cathode and crystals growing on it was carried out in order to grow coarse-crystalline precipitations of copper and to achieve their developed surface. The specific surface of the microcrystalline copper obtained using mechanical activation (Fig. 1b) was $0.9 \mathrm{~m}^{2} / \mathrm{g}$, while that of copper (Fig. 1a) consisting of nanocrystalline grains (with the same mass of the samples) amounted to only $0.02 \mathrm{~m}^{2} / \mathrm{g}$. Thermo Scientific Surfer porosimeter was used to estimate the specific surface. The preliminary gas removal was done for 120 minutes at the temperature of $190^{\circ} \mathrm{C}$. Krypton was used as an adsorbate, and the specific surface was calculated using the Brunauer Emmett - Teller method (BET).

During the second operation, the mesh with the nanocrystalline coating (Fig. 1a) and layers of the defect microcrystals of copper (Fig. 1b) were treated by air annealing at $400^{\circ} \mathrm{C}$ for 4 hours [17-20]. After the annealing layers consisting of copper oxides (Fig. 2) were formed in both coatings (Fig. 1).

The surface morphology of the coatings of the two samples after the annealing was studied with Carl Zeiss Sigma and JEOL JCM 6000 scanning electron microscopes in the secondary electron mode (In-Lens detector), to analyze the composition of elements TEAM EDS accessory by EDAX was used. The cutting of the coatings (samples I and II) and $\mathrm{CuO}$ nanowhiskers was done by the focused beam of ions (FBI)

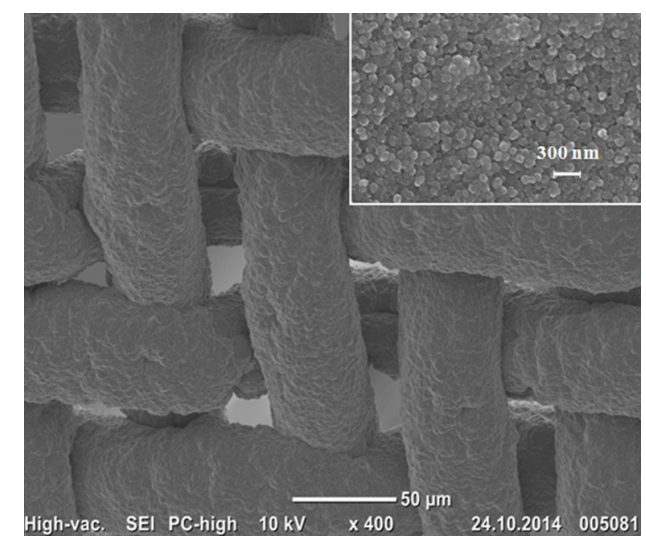

a

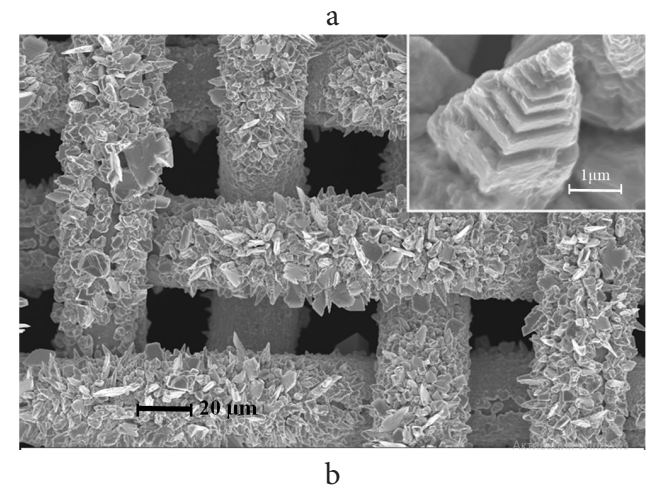

Fig. 1. The electron microscopic pattern (SEM) of the mesh surface after electrodeposition of the copper coatings (sample I) (a) and the layers of the defect crystals deposited using mechanical activation of growing crystals (sample II) (b). 
of gallium in FEI Helions Nanolab 600 scanning electron microscope.

Ion cutting of nanocrystalline copper coatings (sample I), $\mathrm{X}$-ray structure analysis, $\mathrm{X}$-ray electron probe analysis, and scanning electron microscopy allowed a detailed characterization of the laminated coating areas (Fig. 2) formed in the process of annealing of copper precipitations on the meshy support:

- the upper layer consisted of nanowhiskers (Figs. 2,3), the chemical composition of which corresponded to $\mathrm{CuO}$. The whiskers had the diameter from 30 to $100 \mathrm{~nm}$ and the length from 5 to $15 \mu \mathrm{m}$. Their surface density amounted to $10^{9} \mathrm{~cm}^{-2}$;

- the second, dark layer (Fig. 2), which the whiskers grew from, had the thickness of $1.5-2 \mu \mathrm{m}$, contained $49 \%$ of copper and $51 \%$ of oxygen, that is, it compositionally was copper oxide $\mathrm{CuO}$;

- the third, light-grey layer of $2-3 \mu \mathrm{m}$ thickness (Fig. 2) contained $67 \%$ of copper and $33 \%$ of oxygen and was identified as the layer of cuprous oxide $\mathrm{Cu}_{2} \mathrm{O}$ (Fig. 2);

- the fourth, 6-7 $\mu \mathrm{m}$ thick layer, was the layer of pure copper (Fig. 2);

- the last one was the support of $12 \mathrm{X} 18 \mathrm{H} 10 \mathrm{~T}$ steel.

In sample II, the structure of layers of defect crystals formed during annealing of the coating was qualitatively the same.

Thus, whiskers composed of copper oxide were formed on the surface of both samples as a result of air annealing (Fig. 3); their concentration on the surface of the coating from nanocrystalline copper (sample I) is, however, much higher than on the surface from defect microcrystals (sample II). Due to this, the specific surface of the samples was roughly the same and amounted to $10 \mathrm{~m}^{2} / \mathrm{g}$ in the reactions of catalytic oxydation before the tests.

The reactions of catalytic oxidation of carbon monoxide II (1) and methyl alcohol (2) were taken as model reactions:

$$
\begin{gathered}
\mathrm{CO} \underset{\mathrm{CuO}}{\stackrel{\mathrm{O}_{2}}{\longrightarrow}} \mathrm{CO}_{2} \\
\mathrm{CH}_{3} \mathrm{OH} \underset{\mathrm{CuO}}{\stackrel{\mathrm{O}_{2}}{\longrightarrow}} \mathrm{CO}_{2}+2 \mathrm{H}_{2} \mathrm{O}
\end{gathered}
$$

Testing of the samples I and II was carried out in a quartz tube with the inner diameter $3 \mathrm{~mm}$ and the length $40 \mathrm{~cm}$ placed in SUOL-0.25.1/12-I1 tube furnace. Samples of $50 \mathrm{mg}$ mass with $\mathrm{CuO}$ nanowhisker arrays for the case of oxidation of carbon monoxide II (CO) or $200 \mathrm{mg}$ for the oxidation reaction of methyl alcohol (methanol) were preliminarily loaded into the tube. An initial mixture composed of 2 vol\% $\mathrm{CO}$ or methanol and air was injected at a flow rate $10 \mathrm{ml} / \mathrm{min}$. The maximum temperature for heating of the samples in the mixture was set equal to $250^{\circ} \mathrm{C}$ for $\mathrm{CO}$ oxidation and to $320^{\circ} \mathrm{C}$ for methanol oxidation.

The composition of the initial and reaction mixtures was analyzed using Crystallux 4000M gas chromatograph with a thermal conductivity detector (TCD). The concentration of the compounds was determined using the calibration curve. The analysis of $\mathrm{CO}$ and $\mathrm{O}_{2}$ was carried out on a chromatographic tube with a deposited phase $\mathrm{NaX}$ of
3 meters length. The analysis of $\mathrm{CO}_{2}$ and methanol was made on a chromatographic tube with the deposited phase Hyasep Q with 2 meters length.

The regeneration of samples I and II was carried out at temperature $400^{\circ} \mathrm{C}$ for 1 hour in the air stream of $10 \mathrm{ml} / \mathrm{min}$ flow rate without taking them out of the reactor. Then the samples were tested again. The reduction of the samples was carried out in the hydrogen-air mixture ( $2 \mathrm{vol} \%$ of hydrogen) at temperature $300^{\circ} \mathrm{C}$ for 5 hours at the flow rate of the mixture $10 \mathrm{ml} / \mathrm{min}$.

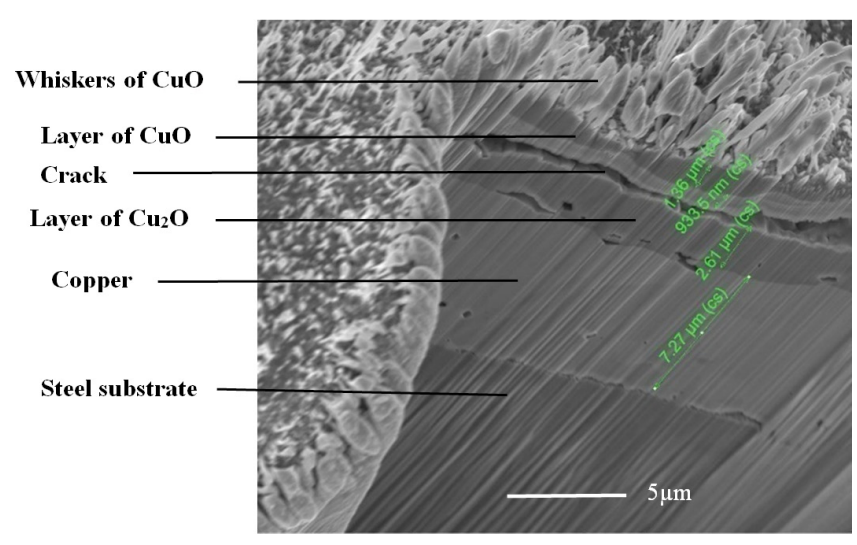

Fig. 2. Electron-microscopic micrograph of a cut of a copper coating (sample I) deposited on the steel mesh support and exposed to annealing at $400^{\circ} \mathrm{C}$ for 4 hours.

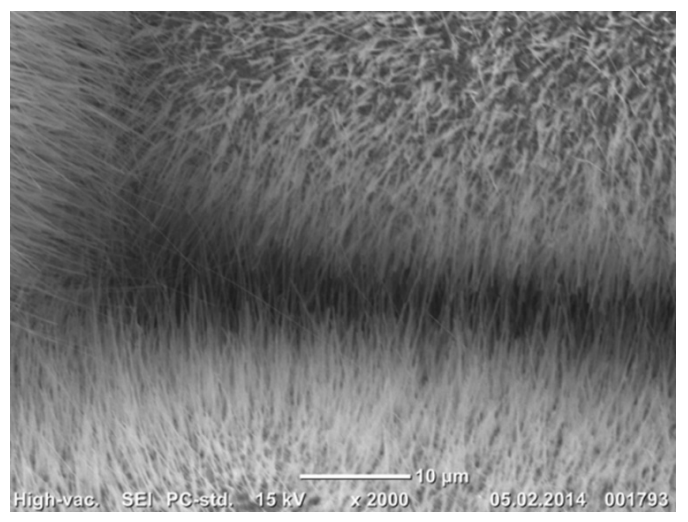

a

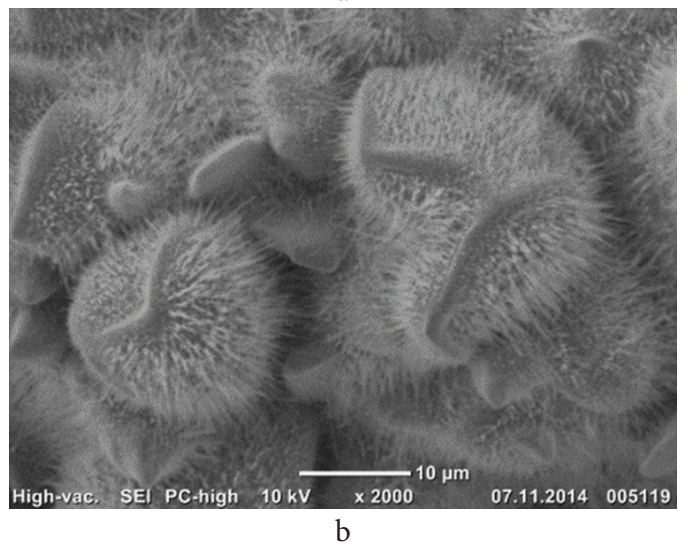

Fig. 3. The surface morphology of catalysts with $\mathrm{CuO}$ nanowhiskers before the oxidation reaction: nanowhisker structures formed on the surface of the solid coating - sample I (a); nanowhisker structures formed on the surface of the defect microcrystal layers sample II (b). 


\section{Results and discussion}

The results of testing of the samples in the reactions of catalytic oxidation of $\mathrm{CO}$ and methanol are presented in Figs. 4 and 5. As seen in Fig. 4, whiskers of copper oxide grown both on nanocrystalline coating and defect microcrystals (Fig. 3) exhibit a high catalytic activity in the reactions of oxidation of $\mathrm{CO}$ and methanol. However, sample I enters into the reaction significantly earlier than sample II. To the authors' opinion, this is due to the fact that sample I has a higher density, smaller diameter, and larger length of whiskers given the same specific surface, as seen from SEM pictures (Fig. 3a,b). It is the higher concentration of whiskers on the surface due to which sample I exhibits a catalytic activity long before than sample II (Fig. 4).

During long-term testing of the samples under investigation in corrosive media and at high temperatures their activity decreases. The graphs in Fig. 5 show that in the oxidation reaction of $\mathrm{CO}$ the conversion of sample I exhibits a twofold drop in about 150 minutes and does not exceed $15 \%$ in 5 hours. Sample II undergoes a significant decrease of catalytic activity as well but with a lower reaction rate.

The samples behave differently from the above behavior in the reaction of methanol oxidation. Sample I exhibits a sharp drop of the activity (by approximately $85 \%$ within five hours). The decrease of catalytic activity for sample II is much slower and the difference between the least and largest values did not exceed $18 \%$ within 5 hours of the experiment. The decrease of activity in both samples is, in our opinion, due to the fracture of the nanowhiskers as a result of the reaction (Fig. 6). A slower decrease of activity of sample II can be caused by the fact that not only whiskers composed of copper oxide react in the catalytic oxidation reactions but also the surface layer of the sample, which, according to preliminary studies (see Fig. 2), is composed of $\mathrm{CuO}$ as well but has a more developed initial surface (Fig. 1b, 3d) due to the defect crystals formed in the process of copper electrocrystallization during mechanical activation of the cathode.

After testing of the samples fracture of the whisker structures is observed (Fig. 6b). According to the data obtained by means of scanning electron microscopy, the mean length of the whiskers is decreased by $40-50 \%$. A formation of thickenings is observed on them (Fig. 6b), a particularly large number of which is observed on the bends and ends of the whiskers. This, in our opinion, is due to a large number of the cycles of copper valence change and crystal lattice rearrangement $\mathrm{Cu} \rightarrow \mathrm{CuO} \rightarrow \mathrm{Cu}_{2} \mathrm{O}$ in more defected and, therefore, more catalytically active parts of the whisker.

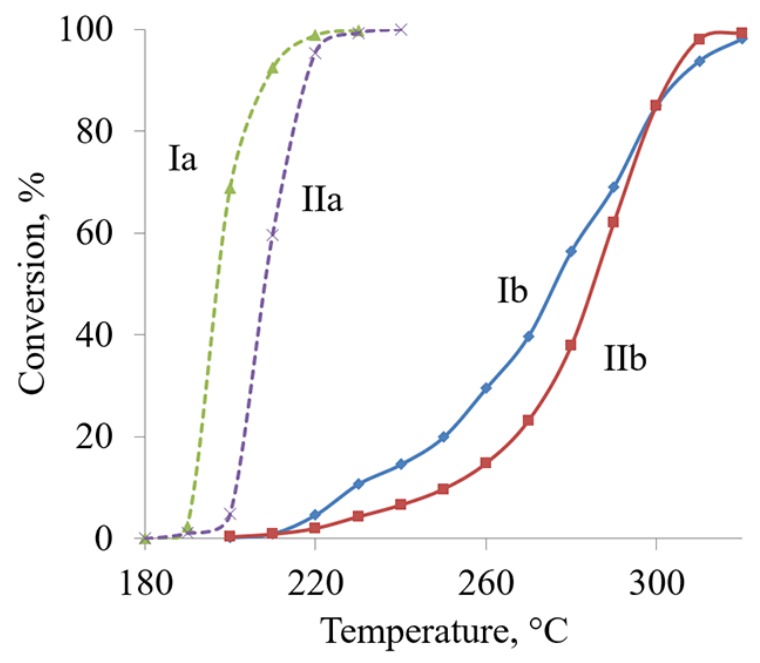

Fig. 4. Plots of the degree of CO (a) and methanol (b) oxidation against the temperature for sample I and sample II.

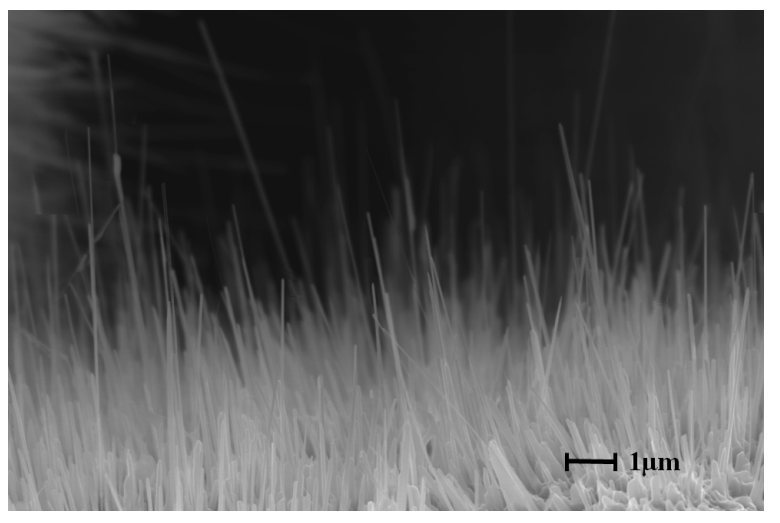

a

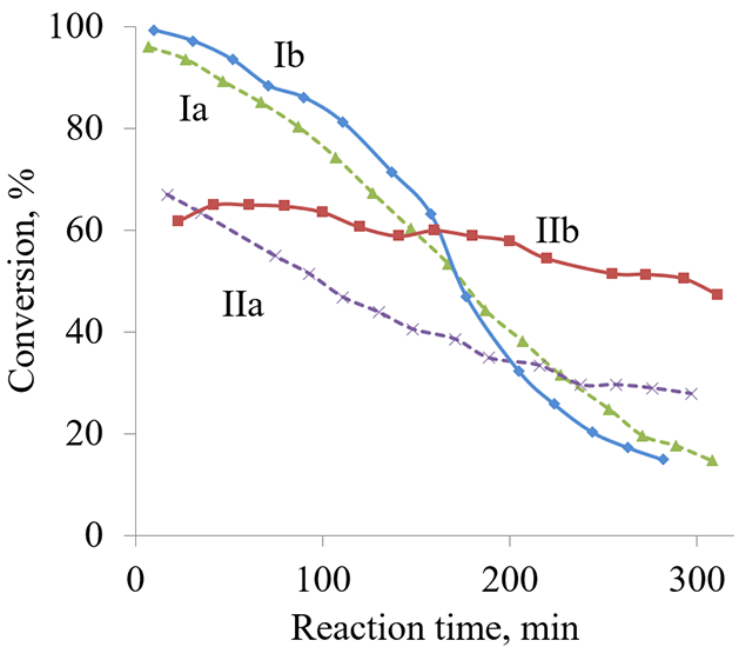

Fig. 5. Plots of oxidation of $\mathrm{CO}$ (a) and methanol (b) at $T=300^{\circ} \mathrm{C}$ for sample I and sample II.

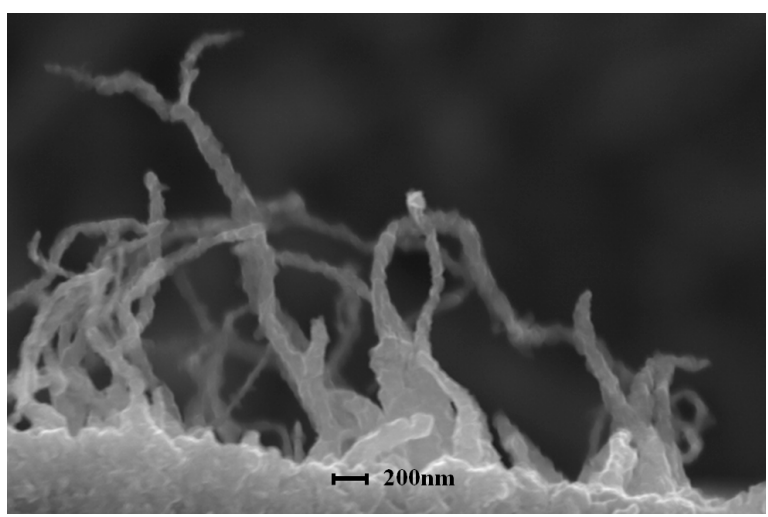

b

Fig. 6. Appearance of nanowhiskers: before the test (a); after the oxidation reaction (b). 
A large difference in specific volumes of $\mathrm{Cu}, \mathrm{CuO}, \mathrm{Cu}_{2} \mathrm{O}[11$, 12] results in the fracture of the whiskers structure due to a large number of cycles of reduction and oxidation of copper. The $\mathrm{Cu}_{2} \mathrm{O}$ crystal lattice is the "loosest" one that is why cracks are formed in $\mathrm{Cu}_{2} \mathrm{O}$ layer during the heat treatment of copper (Fig. 2).

To clarify the reasons for the fracture of whiskers, we carried out temperature tests in vacuum under the conditions similar to those of catalytic activity testing. No visible whiskers fracture is observed in vacuum suggesting that it is is not due to the heating of whiskers up to high temperatures but to the redox processes.

Thus, in our opinion, the decrease of catalytic activity of the samples is caused by a reduction of their surface area due to the fracture of whiskers under the conditions of catalytic oxidation.

\section{Conclusion}

Basing on the results of the present study, the following conclusions can be made:

- application of whisker structures obtained on the surface of metallic supports and fully composed of copper oxide in corrosive media, in particular, in the reaction of catalytic oxidation of $\mathrm{CO}$ and methanol is counterproductive due to their fracture;

- the fracture of whiskers in the process of the reaction is due to their oxidation and reduction, but not to any thermal or physical impact. A periodic rearrangement of the crystal lattice occurs under oxidation and reduction of copper oxides, and due to the large difference in the specific volumes of $\mathrm{Cu}, \mathrm{CuO}$ and $\mathrm{Cu}_{2} \mathrm{O}$ this results in the fracture of the lattice;

- whiskers and nanowhisker structures of copper oxide can be more efficiently used in catalytic reactions at relatively low temperatures (below $200^{\circ} \mathrm{C}$ ), for example, as photocatalysts active in the visible range of electromagnetic radiation [10] and used for decontamination of toxic substances;

- whisker structures of copper oxide can be used at higher temperatures (up to $500^{\circ} \mathrm{C}$ ) but in inert media and vacuum.

Acknowledgements. The reported study was funded by RFBR according to the research project № 16-02-00517 $a$.

\section{References}

1. P. R. Shukla, Sh.Wang, H. Ming Ang, M.O. Tadé. Separation and Purification Technology. 70, 338 (2010).

2. H. Benhebal, M. Chaib, A. Leonard, S.D. Lambert, M. Crine. Materials Science in Semiconductor Processing. 15, 264 (2012).
3. R. B. Raj, M. Umadevi, V.P. Parvathi and R. Parimaladevi. Adv. Nat. Sci.: Nanosci. Nanotechnol. 7, 045008 (2016).

4. R. Poreddy, C. Engelbrekt, A. Riisager. Catal. Sci. Technol. 5, 2467 (2015).

5. D.M. Matthew, J.M. Colin et al. ACS Catalysis. 5(12), 1916 (2015).

6. M.Y. Hamid, A. Ehab. Indian Journal of Science and Technology. 7(12), 7371 (2014).

7. Y.Z. Feng, X. L. Zheng. Nano Lett. 10, 4762 (2010).

8. Y. Feng, P. M. Rao, D. R Kim, X. Zheng. P. Combust. Inst. 33, 3169 (2011).

9. M. B. Gawande, A. Goswami, F.-X. Felpin, T. Asefa, X. Huang, R. Silva, X. Zou, R. Zboril, R. S. Varma. Chem. Rev. 116, 3722 (2016).

10. Q. Zahng, K. Zhang, D. Xu, G. Yang, H. Huang, F. Nie, C. Liu, S. Yang. Prog. Mater. Sci. 60, 208 (2014).

11. A.N. Priezzheva, M.V. Dorogov, M.N. Tyurkov et al. Bulletin of the Russian Academy of Sciences: Physics. 9(79), 1098 (2015). (in Russian) [А.Н. Приезжева, М.В. Дорогов, М.Н. Тюрьков и др. Известия Российской академии наук. Серия физическая. 9(79), 1243 (2015).]

12. A.N. Abramova, A.A. Vikarchuk. Vektor nauki Tolyattinskogo gosudarstvennogo universiteta. 3(25), 105 (2013). (in Russian) [А.Н. Абрамова, А. А. Викарчук. Вектор науки Тольяттинского государственного университета. 3(25), 105 (2013).]

13. N.N. Gryzunova, A.A. Vikarchuk, V.V. Bekin, A.E. Romanov. Bulletin of the Russian Academy of Sciences: Physics. 79(9), 1093 (2015). (in Russian) [Н.Н. Грызунова, А.А. Викарчук, В.В. Бекин, А.Е. Романов. Известия Российской академии наук. Серия физическая. 79(9), 1238 (2015).]

14. N.N. Gryzunova, A.A. Vikarchuk, M.N. Tyur'kov. Russian Metallurgy (Metally). 10, 924 (2016). (in Russian) [Н.Н. Грызунова, А.А. Викарчук, М.Н. Тюрьков. Деформация и разрушение материалов. 2, 13 (2016).]

15. N.N. Gryzunova, A.A. Vikarchuk, A.M. Gryzunov, A. E. Romanov. Materials Physics and Mechanics. 2(32), 144 (2017).

16. N. N. Gryzunova. Letters on Materials. 1(7), 39 (2017) (in Russian) [Н.Н. Грызунова. Письма о материалах. 7(1), 39 (2017).] DOI: 10.22226/2410-3535-2017-1-39-43

17. Q. Zhang, K. Zhang, D. Xu, G. Yang, H. Huang, F. Nie, C. Liu, S. Yang. Progress in Materials Science. 60, 208 (2014).

18. Y.H. Cheng, Y.J. Lin, J.P. Xu, J He, T.Z. Wang, G. J. Yu, D. W. Shao, W.-H. Wang, F. Lu, L. Li, X. W. Du, W. Wang, H. Liu, R. Zheng. Appl. Surf. Sci. 366, 120 (2016).

19. U. Nerle, M. K. Rabinal. IOSR Journal of Applied Physics. 5, 01 (2013).

20. C. J. Love, J. D. Smith, Y. H. Cui, K. K. Varanasi. Nanoscale. 3, 4972 (2011). 